See discussions, stats, and author profiles for this publication at: https://www.researchgate.net/publication/327902533

\title{
Experimental and theoretical investigations on the optical and electrochemical properties of $\pi$-conjugated donor-acceptor-donor (DAD) compounds toward a universal model
}

Article in The Journal of Chemical Physics · September 2018

DOI: $10.1063 / 1.5049670$

CITATIONS

10 authors, including:

Christos L. Chochos

National Hellenic Research Foundation

84 PUBLICATIONS 2,150 CITATIONS

SEE PROFILE

Ibrahim Bulut

Çanakkale Onsekiz Mart Üniversitesi

70 PUBLICATIONS 419 CITATIONS

SEE PROFILE

Some of the authors of this publication are also working on these related projects:

MatHero - New materials for highly efficient and reliable organic solar cells View project

Organic photovoltaics View project
READS

98

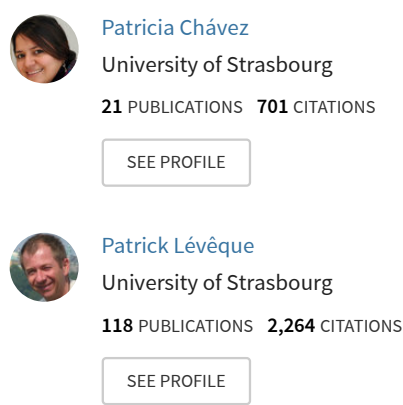




\section{Experimental and theoretical investigations on the optical and electrochemical properties of $\pi$-conjugated donor-acceptor-donor (DAD) compounds toward a universal model}

Christos L. Chochos, Patricia Chávez, Ibrahim Bulut, Patrick Lévêque, Michael Spanos, Elisavet Tatsi, Athanasios Katsouras, Apostolos Avgeropoulos, Vasilis G. Gregoriou, and Nicolas Leclerc

Citation: The Journal of Chemical Physics 149, 124902 (2018); doi: 10.1063/1.5049670

View online: https://doi.org/10.1063/1.5049670

View Table of Contents: http://aip.scitation.org/toc/jcp/149/12

Published by the American Institute of Physics 


\title{
Experimental and theoretical investigations on the optical and electrochemical properties of $\pi$-conjugated donor-acceptor-donor (DAD) compounds toward a universal model
}

\author{
Christos L. Chochos, ${ }^{1,2, a)}$ Patricia Chávez, ${ }^{3}$ Ibrahim Bulut, ${ }^{3}$ Patrick Lévêque, ${ }^{4}$ \\ Michael Spanos, ${ }^{1,5}$ Elisavet Tatsi, ${ }^{1}$ Athanasios Katsouras, ${ }^{1}$ Apostolos Avgeropoulos, ${ }^{1}$ \\ Vasilis G. Gregoriou, ${ }^{5}$ and Nicolas Leclerc ${ }^{3, a)}$ \\ ${ }^{1}$ Department of Materials Science Engineering, University of Ioannina, Ioannina 45110, Greece \\ ${ }^{2}$ Advent Technologies SA, Patras Science Park, Platani Rio, 26504 Patras, Greece \\ ${ }^{3}$ Institut de Chimie et Procédés pour l'Energie, l'Environnement et la Santé, Université de Strasbourg, Ecole \\ Européenne de Chimie, Polymères et Matériaux, 25 Rue Becquerel, 67087 Strasbourg, France \\ ${ }^{4}$ Laboratoire ICube, CNRS, Université de Strasbourg, UMR7357, 23 Rue du Loess, 67037 Strasbourg, France \\ ${ }^{5}$ National Hellenic Research Foundation (NHRF), 48 Vassileos Constantinou Avenue, Athens 11635, Greece
}

(Received 24 July 2018; accepted 7 September 2018; published online 26 September 2018)

\begin{abstract}
A series of nine (9) donor-acceptor-donor (DAD) $\pi$-conjugated small molecules were synthesized via palladium catalyzed Stille aromatic cross-coupling reactions by the combination of six (6) heterocycle building blocks (thiophene, furan, thiazole, 2,1,3-benzothiadiazole, 2,1,3-pyridinothiadiazole, thienothiadiazole) acting as electron donating (thiazole, furan, thiophene) and electron deficient (benzothiadiazole, pyridinethiadiazole, thienothiadiazole) units. These model compounds enable determining the correspondence between the theoretical and experimental optical and electrochemical properties for the first time, via Density Functional Theory (DFT), time-dependent DFT, UV-Vis spectroscopy, and cyclic voltammetry, accordingly. The obtained theoretical models can be utilized for the design and synthesis of new DAD structures with precise optical bandgaps, absorption maxima, and energy levels suitable for different optoelectronic applications. Published by AIP Publishing. https://doi.org/10.1063/1.5049670
\end{abstract}

\section{INTRODUCTION}

The fast growing interdisciplinary terrain of organic electronics exploits organic molecular materials as semiconductors and active components in devices. ${ }^{1,2}$ The performance of devices, such as organic photovoltaics (OPVs), ${ }^{3}$ dye-sensitized solar cells (DSSCs), ${ }^{4}$ organic field-effect transistors (OFETs) ${ }^{5}$ organic light-emitting diodes (OLEDs), ${ }^{6}$ electrochromic devices (ECDs), ${ }^{7}$ and organic photodetectors (OPDs), ${ }^{8}$ is often encountered from the capability to precisely tune properties such as conductivity, charge-carrier mobility, light absorption, and light emission in $\pi$-conjugated materials.

The plethora of chemical modifications that are used to engineer and optimize the physical and optoelectronic properties that suit specific purposes in organic electronic materials (small molecules and conjugated polymers) has established them during the past few decades as dominate materials for various optoelectronic applications. ${ }^{9}$ Thus, organic chemists must carefully manage and often achieve a balance between various redox, optical, and electronic properties in both conjugated polymers and small molecules. Energies of both the highest occupied molecular orbital $\left(E_{\text {НОмо }}\right)$, associated with

\footnotetext{
a) Authors to whom correspondence should be addressed: leclercn@unistra.fr and cchochos@advent-energy.com
}

the ionization energy (IE) of the molecule, and the lowest unoccupied molecular orbital $\left(E_{L U M O}\right)$, which relates to the electron affinity (EA) of the molecule or polymer, as well as the energy gap $\left(E_{g}\right)$, appear essential in order to tune the material's electronic properties. Undeniably, despite the fact that other material properties, such as molecular weight and morphology/microstructure, play a critical role, ${ }^{10-12}$ IE and EA typically must be properly aligned corresponding to the work functions, IEs, or EAs of known electrode materials, interfacial materials, and/or other adjacent organic layers to ensure efficient charge-carrier injection or extraction, or photoinduced charge separation in devices. ${ }^{13,14}$

A fine way to tune the properties of $\pi$-conjugated small molecules or polymers ${ }^{15,16}$ is the covalent coupling of at least one electron donating (D) to at least one electron deficient (A) unit, directly or through a $\pi$-conjugated linkage $(\pi)$. Considerable distinctive structural motifs have been broadly studied during the past two decades, leading to great advances in (i) second-order and third-order nonlinear optical (NLO) chromophores (D- $\pi-\mathrm{A}) ;{ }^{17-19}$ (ii) two-photon absorbing (TPA) chromophores (D-A-D, D- $\pi-\mathrm{A}$, and A-D-A); ${ }^{20,21}$ (iii) electrochromics $\left.\left(-\mathrm{D}_{\mathrm{n}}-\mathrm{A}-\right)\right)^{22-25}$ (iv) chromophores for dye sensitized solar cells (DSSCs, D- $\pi-\mathrm{A}$, and $\mathrm{D}_{2} \mathrm{~A}$ ) ${ }^{26-29}$ (v) polymers $(-\mathrm{D}-\mathrm{A}-)_{\mathrm{n}}$ and small molecules (D-A) for OLEDs ${ }^{30}$ (vi) small molecule donors (D-A, D-A-D, and A-D-A) $)^{31,32}$ and acceptors $^{33}$ and polymers (-D-A-) for OPVs $;^{34-39}$ (vii) polymers 

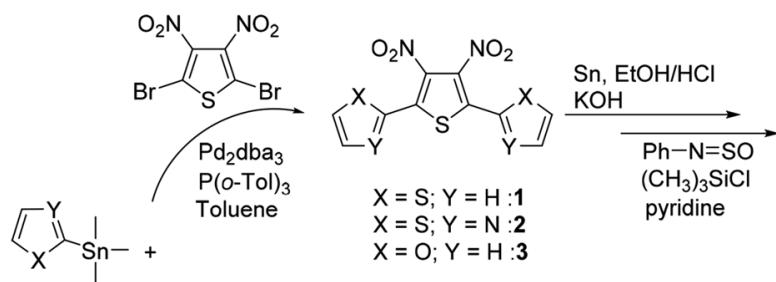

$\mathrm{X}=\mathrm{S} ; \mathrm{Y}=\mathrm{H}: 1$

$\mathrm{X}=\mathrm{S} ; \mathrm{Y}=\mathrm{N}: 2$

$\mathrm{X}=\mathrm{O} ; \mathrm{Y}=\mathrm{H} \cdot 3$
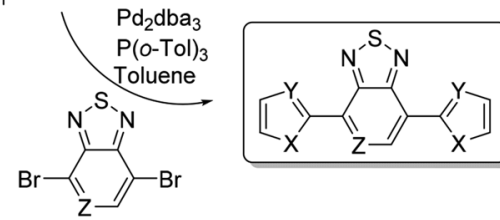

$X=\mathrm{S} ; Y=\mathrm{H} ; \mathrm{Z}=\mathrm{C}$ :T-BTD-T

$X=S ; Y=N ; Z=C \cdot T Z-B T D-T Z$

$X=O ; Y=H ; Z=C$ :F-BTD-F

$\mathrm{X}=\mathrm{S} ; \mathrm{Y}=\mathrm{H} ; \mathrm{Z}=\mathrm{N}: \mathrm{T}-\mathrm{PTD}-\mathrm{T}$

$\mathrm{X}=\mathrm{S} ; \mathrm{Y}=\mathrm{N} ; \mathrm{Z}=\mathrm{N}:$ TZ-PTD-TZ

$X=O ; Y=H ; Z=N$ :F-PTD-F
FIG. 1. Synthetic pathway and general chemical structures of the developed 9 DAD triads.
$(-\mathrm{D}-\mathrm{A}-)_{\mathrm{n}}$ for OFETs ${ }^{40,41}$ and (viii) polymers $(-\mathrm{D}-\mathrm{A}-)_{\mathrm{n}}$ for electrochromism. ${ }^{25,42}$

In this work, correlation between the theoretical and experimental optical and electrochemical properties has been achieved for the first time, to the best of our knowledge, for the D-A-D triads by the synthesis of a series of D-A-D monomers consisting of various electron donating [thiazole $(\mathrm{Tz})$, furan $(\mathrm{F})$, thiophene $(\mathrm{T})]$ and electron deficient $[2,1,3$ benzothiadiazole (BTD), 2,1,3-pyridinothiadiazole (PTD), thienothiadiazole (TTD)] building blocks of varying strengths (Fig. 1). The obtained theoretical models can be utilized for the design and synthesis of a plethora of new (donor-acceptordonor) DAD structures with precise optical bandgaps, absorption maxima, and energy levels suitable for different optoelectronic applications.

\section{EXPERIMENTAL}

\section{A. Materials}

All solvents, reagents, and all deuterated solvents were purchased from Aldrich and Euroisotop. Column chromatography was performed with silica gel (Sigma-Aldrich, type 60, 0.063-0.2 mm). NMR spectra were recorded on a Bruker Avance 300 and Avance $400 \mathrm{MHz}$ spectrometer, respectively. All chemical shifts in NMR experiments are reported as ppm downfield from TMS (tetramethylsilane). The following calibrations were used: $\mathrm{CD}_{2} \mathrm{Cl}_{2} \delta=5.32$ and $53.84 \mathrm{ppm}$; $\mathrm{CDCl}_{3} \delta=7.26$ and $77.0 \mathrm{ppm}$. MS(EI) [mass spectrometry (EI means electron ionization)] and HRMS (high resolution mass spectrometry) experiments were performed on a Bruker micrOTOF-Q mass spectrometer within the service centers at Strasbourg University.

\section{General Stille procedure}

A flame dried Schlenck was charged with the dibromo (A) compounds (1.0 equiv) and $\mathrm{P}(o \text {-tolyl })_{3}(0.08$ equiv $)$. Anhydrous and degassed toluene $(0.1 \mathrm{M})$ was added under inert gas followed by the trimethylstannyl (D) derivatives (2.2 equiv). Finally $\mathrm{Pd}_{2} \mathrm{dba}_{3}$ ( 0.04 equiv) was added in one portion and the mixture was stirred $12 \mathrm{~h}$ at $120^{\circ} \mathrm{C}$. After cooling to room temperature, the reaction mixtures were evaporated under reduced pressure and purified by column chromatography.

4,7-di(thiophen-2-yl)benzo[c][1,2,5]thiadiazole (T-BTDT). Obtained as an orange solid in $81 \%$ yield. ${ }^{1} \mathrm{H}$ NMR (300 $\left.\mathrm{MHz} \mathrm{CDCl}_{3}\right) \delta=8.16(\mathrm{dd}, J=3.5,1.1 \mathrm{~Hz}, 2 \mathrm{H}), 7.89(\mathrm{~s}, 2 \mathrm{H})$, $7.51(\mathrm{dd}, J=5.2,1.1 \mathrm{~Hz}, 2 \mathrm{H}), 7.19(\mathrm{dd}, J=5.2,3.5 \mathrm{~Hz}, 2 \mathrm{H})$. ${ }^{13} \mathrm{C} \mathrm{NMR}\left(100 \mathrm{MHz}, \mathrm{CDCl}_{3}\right) \delta=153.5,139.5,126.7,127.4$, 126.4, 126.1, 125.7. MS (ESI-TOF): $m / z(\%): 301.0[\mathrm{M}+\mathrm{H}]^{+}$ (100). HRMS-ESI-TOF $m / z$ calculated for $\mathrm{C}_{14} \mathrm{H}_{9} \mathrm{~N}_{2} \mathrm{~S}_{3}[\mathrm{M}+$ $\mathrm{H}]^{+}$: 300.992; found: 300.992 .

4,7-di(furan-2-yl)benzo[c][1,2,5]thiadiazole (F-BTD-F). Obtained as an orange solid in $78 \%$ yield. ${ }^{1} \mathrm{H}$ NMR $(300 \mathrm{MHz}$, $\left.\mathrm{CD}_{2} \mathrm{Cl}_{2}\right) \delta=6.64(\mathrm{dd}, J=1.7,3.4 \mathrm{~Hz}, 1 \mathrm{H}), 7.61(\mathrm{~d}, J=1.7$ $\mathrm{Hz}, 1 \mathrm{H}), 7.67(\mathrm{~d}, J=3.4 \mathrm{~Hz}, 1 \mathrm{H}), 8.02(\mathrm{~s}, 1 \mathrm{H}) .{ }^{13} \mathrm{C} \mathrm{NMR}$ $\left(100 \mathrm{MHz}, \mathrm{CD}_{2} \mathrm{Cl}_{2}\right) \delta=112.6,112.8,122.1,123.8,143.3$, 150.5, 151.7. MS (ESI-TOF): $m / z(\%): 269.0[\mathrm{M}+\mathrm{H}]^{+}(100)$. HRMS-ESI-TOF $m / z$ calculated for $\mathrm{C}_{14} \mathrm{H}_{9} \mathrm{~N}_{2} \mathrm{O}_{2} \mathrm{~S}[\mathrm{M}+\mathrm{H}]^{+}$: 269.038; found: 269.035 .

4,7-di(thiazol-2-yl)benzo[ $[c][1,2,5]$ thiadiazole (Tz-BTDTz). Obtained as an orange solid in $70 \%$ yield. ${ }^{1} \mathrm{H}$ NMR (300 $\left.\mathrm{MHz} \mathrm{CDCl}_{3}\right) \delta=8.73(\mathrm{~s}, 2 \mathrm{H}), 8.06(\mathrm{~d}, J=3.2 \mathrm{~Hz}, 2 \mathrm{H}), 7.62$ $(\mathrm{d}, J=3.2 \mathrm{~Hz}, 2 \mathrm{H}) .{ }^{13} \mathrm{C} \mathrm{NMR}\left(100 \mathrm{MHz}, \mathrm{CD}_{2} \mathrm{Cl}_{2}\right) \delta=161.9$, 152.0, 143.5, 127.4, 126.6, 122.4. MS (ESI-TOF): $\mathrm{m} / z(\%)$ : $303.0[\mathrm{M}+\mathrm{H}]^{+}(100)$. HRMS-ESI-TOF $\mathrm{m} / z$ calculated for $\mathrm{C}_{12} \mathrm{H}_{7} \mathrm{~N}_{4} \mathrm{~S}_{3}[\mathrm{M}+\mathrm{H}]^{+}:$302.983; found: 302.984 .

4,7-di(thiophen-2-yl)-[1,2,5]thiadiazolo[3,4-c]pyridine (TPTD-T). Obtained as an orange solid in $74 \%$ yield. ${ }^{1} \mathrm{H}$ NMR $\left(300 \mathrm{MHz}, \mathrm{CD}_{2} \mathrm{Cl}_{2}\right) \delta=7.23(\mathrm{dd}, J=3.7,5.0 \mathrm{~Hz}, 1 \mathrm{H}), 7.26$ $(\mathrm{dd}, J=3.8,5.0 \mathrm{~Hz}, 1 \mathrm{H}), 7.51(\mathrm{dd}, J=1.0,5.1 \mathrm{~Hz}, 1 \mathrm{H}), 7.60$ $(\mathrm{dd}, J=1.0,5.1 \mathrm{~Hz}, 1 \mathrm{H}), 8.11(\mathrm{dd}, J=1.0,3.7 \mathrm{~Hz}, 1 \mathrm{H}), 8.69$ $(\mathrm{dd}, J=1.0,3.7 \mathrm{~Hz}, 1 \mathrm{H}), 8.82(\mathrm{~s}, 1 \mathrm{H}) .{ }^{13} \mathrm{C} \mathrm{NMR}(100 \mathrm{MHz}$, $\left.\mathrm{CD}_{2} \mathrm{Cl}_{2}\right) \delta=120.9,127.7,128.3,128.5,129.3,130.9,132.2$, 137.0, 141.1, 142.4, 146.8, 148.4, 155.3. MS (ESI-TOF): $\mathrm{m} / \mathrm{z}$ (\%): $302.0[\mathrm{M}+\mathrm{H}]^{+}(100)$. HRMS-ESI-TOF $m / z$ calculated for $\mathrm{C}_{13} \mathrm{H}_{8} \mathrm{~N}_{3} \mathrm{~S}_{3}[\mathrm{M}+\mathrm{H}]^{+}$: 301.987; found: 301.986 .

4,7-di(furan-2-yl)-[1,2,5]thiadiazolo[3,4-c $]$ pyridine (F-PTD-F). Obtained as an orange solid in $60 \%$ yield. ${ }^{1} \mathrm{H}$ NMR $\left(300 \mathrm{MHz}, \mathrm{CDCl}_{3}\right) \delta=10.90(\mathrm{~s}, 1 \mathrm{H}), 9.90(\mathrm{dd}, J=0.8,3.5$ $\mathrm{Hz}, 1 \mathrm{H}), 9.72(\mathrm{dd}, J=0.8,1.7 \mathrm{~Hz}, 1 \mathrm{H}), 9.60(\mathrm{dd}, J=0.8,3.5$ $\mathrm{Hz}, 1 \mathrm{H}), 9.58$ (d, $J=0.8,3.5 \mathrm{~Hz}, 1 \mathrm{H}), 8.67$ (dd, $J=1.7,35$ $\mathrm{Hz}, 1 \mathrm{H}), 8.61(\mathrm{dd}, J=1.8,3.5 \mathrm{~Hz}, 1 \mathrm{H}) .{ }^{13} \mathrm{C} \mathrm{NMR}(100 \mathrm{MHz}$, $\left.\mathrm{CD}_{2} \mathrm{Cl}_{2}\right) \delta=155.2,152.4,150.2,149.47,147.5,145.3,143.9$, 141.0, 119.0, 118.3, 115.0, 114.7, 114.4. MS (ESI-TOF): $\mathrm{m} / \mathrm{z}$ (\%): $270.0[\mathrm{M}+\mathrm{H}]^{+}(100)$. HRMS-ESI-TOF $m / z$ calculated for $\mathrm{C}_{13} \mathrm{H}_{8} \mathrm{~N}_{3} \mathrm{O}_{2} \mathrm{~S}[\mathrm{M}+\mathrm{H}]^{+}:$270.033; found: 270.031 .

4,7-di(thiazol-2-yl)-[1,2,5]thiadiazolo[3,4-c]pyridine (TzPTD-Tz). Obtained as a yellow-orange solid in 53\% yield. ${ }^{1} \mathrm{H}$ NMR $\left(300 \mathrm{MHz}, \mathrm{CD}_{2} \mathrm{Cl}_{2}\right) \delta=7.07$ (t, $\left.J=3.1 \mathrm{~Hz}, 2 \mathrm{H}\right)$, $8.09(\mathrm{~d}, J=3.1 \mathrm{~Hz}, 1 \mathrm{H}), 8.20(\mathrm{~d}, J=3.1 \mathrm{~Hz}, 1 \mathrm{H}), 9.60(\mathrm{~s}$, 1H). ${ }^{13} \mathrm{C}$ NMR $\left(100 \mathrm{MHz}, \mathrm{CD}_{2} \mathrm{Cl}_{2}\right) \delta=121.3,122.9,123.7$, 
$141.8,143.8,145.8,146.2,147.4,155.0,160.0,165.8 . \mathrm{MS}$ (ESI-TOF): $m / z(\%): 326.0[\mathrm{M}+\mathrm{Na}]^{+}(100)$. HRMS-ESI-TOF $m / z$ calculated for $\mathrm{C}_{11} \mathrm{H}_{5} \mathrm{~N}_{5} \mathrm{NaS}_{3}[\mathrm{M}+\mathrm{Na}]^{+}: 325.960$; found: 325.960 .

Compound 1. Obtained, after a column chromatography (petroleum ether/ethyl acetate in a 95/5 ratio as eluent), as dark powder in $47 \%$ yield. ${ }^{1} \mathrm{H}$ NMR (300 MHz, DMSO) $\delta=8.02(\mathrm{dd}, J=1.2,3.4 \mathrm{~Hz}, 2 \mathrm{H}), 7.71(\mathrm{dd}, J=1.2,5.6$ $\mathrm{Hz}, 2 \mathrm{H}), 7.30$ (dd, $J=3.4,5.6 \mathrm{~Hz}, 2 \mathrm{H}) .{ }^{13} \mathrm{C}$ NMR $(100 \mathrm{MHz}$, $\left.\mathrm{CDCl}_{3}\right) \delta=134.2,132.8,132.2,128.7,127.2$.

Compound 2. Obtained, after a column chromatography (petroleum ether/ethyl acetate in a 95/5 ratio as eluent), as dark powder in $33 \%$ yield. ${ }^{1} \mathrm{H}$ NMR $\left(300 \mathrm{MHz}, \mathrm{CDCl}_{3}\right.$ ) $\delta=8.03(\mathrm{~d}, J=3.1 \mathrm{~Hz}, 2 \mathrm{H}), 7.70(\mathrm{~d}, J=3.1 \mathrm{~Hz}, 2 \mathrm{H}) .{ }^{13} \mathrm{C} \mathrm{NMR}$ $\left(100 \mathrm{MHz}, \mathrm{CDCl}_{3}\right) \delta=131.7,131.3,131.2,128.4,128.1$.

Compound 3. Obtained as dark powder in $57 \%$ yield, after a column chromatography (petroleum ether/ethyl acetate in a 95/5 ratio as eluent). ${ }^{1} \mathrm{H}$ NMR $\left(300 \mathrm{MHz}, \mathrm{CDCl}_{3}\right) \delta=7.90$ $(\mathrm{dd}, J=1.2,3.4 \mathrm{~Hz}, 2 \mathrm{H}), 7.58(\mathrm{dd}, J=1.2,5.6 \mathrm{~Hz}, 2 \mathrm{H})$, $7.15(\mathrm{dd}, J=3.4,5.6 \mathrm{~Hz}, 2 \mathrm{H}) .{ }^{13} \mathrm{C} \mathrm{NMR}\left(100 \mathrm{MHz}, \mathrm{CDCl}_{3}\right)$ $\delta=127.6,125.8,124.1,121.6,120.9$.

\section{Thiadiazole cyclization general procedure}

The cyclization is a two-step reaction that involves first a dinitro derivative reduction into a diamino derivative. Compounds 1, 2, and 3 were stirred in EtOH with a large excess of $\mathrm{Pd} / \mathrm{C}$. Then a large excess of hydrazine monohydrate $(100$ equiv) was added and the solution was stirred for two additional hours. The solution was then filtered on a celite pad and dissolved in dichloromethane $\left(\mathrm{CH}_{2} \mathrm{Cl}_{2}\right)$. The organic phase was washed successively with $\mathrm{NH}_{4} \mathrm{Cl}, \mathrm{NaHCO}_{3}$, and pure water. The organic phase was then dried onto $\mathrm{Na}_{2} \mathrm{SO}_{4}$ and then the solvent evaporated under reduced pressure. The crude diamino products were immediately used in the next cyclization step. They were dissolved in dry pyridine $(10 \mathrm{ml}$ per $\mathrm{mmol}$ of the diamino compound) under $\mathrm{Ar}$ and the solution was warmed at $80^{\circ} \mathrm{C}$. $N$-thionyaniline was then added ( 2 equiv). After $5 \mathrm{~min}$, chlorotrimethylsilane ( 7 equiv) was added and the solution was stirred for $150 \mathrm{~min} . \mathrm{CH}_{2} \mathrm{Cl}_{2}$ was then added to the reaction and the organic phase was washed two times with $\mathrm{HCl} 1 \mathrm{~N}$ and finally with pure water. The organic phase was then dried onto $\mathrm{Na}_{2} \mathrm{SO}_{4}$ and then the solvent evaporated under reduced pressure. Crude products were then purified by column chromatography (petroleum ether/ $\mathrm{CH}_{2} \mathrm{Cl}_{2}$ in a $90 / 10$ ratio as eluent).

4,6-di(thiophen-2-yl)-[3,4-c][1,2,5]thiadiazole (T-TTD-T). Obtained as a blue solid in $42 \%$ yield. ${ }^{1} \mathrm{H}$ NMR $(300 \mathrm{MHz}$, $\left.\mathrm{CD}_{2} \mathrm{Cl}_{2}\right) \delta=7.12(\mathrm{dd}, J=3.7,5.1 \mathrm{~Hz}, 1 \mathrm{H}), 7.35(\mathrm{dd}, J=1.0$, $5.1 \mathrm{~Hz}, 1 \mathrm{H}), 7.57(\mathrm{dd}, J=1.0,3.7 \mathrm{~Hz}, 1 \mathrm{H}) .{ }^{13} \mathrm{C}$ NMR $(100$ $\left.\mathrm{MHz}, \mathrm{CD}_{2} \mathrm{Cl}_{2}\right) \delta=112.8,124.7,125.9,128.6,135.3,156.7$. MS (ESI-TOF): $m / z(\%): 306.9[\mathrm{M}+\mathrm{H}]^{+}(100)$. HRMS-ESITOF $m / z$ calculated for $\mathrm{C}_{12} \mathrm{H}_{7} \mathrm{~N}_{2} \mathrm{~S}_{4}[\mathrm{M}+\mathrm{H}]^{+}: 306.949$; found: 306.945 .

4,6-di(furan-2-yl)-[3,4-c][1,2,5]thiadiazole (F-TTD-F). Obtained as a blue solid in $35 \%$ yield. ${ }^{1} \mathrm{H}$ NMR $(300 \mathrm{MHz}$, $\left.\mathrm{CD}_{2} \mathrm{Cl}_{2}\right) \delta=6.59(\mathrm{dd}, J=1.8,3.3 \mathrm{~Hz}, 1 \mathrm{H}), 7.02(\mathrm{~d}, J=3.3$, $1 \mathrm{H}), 7.49$ (d, $J=1.8 \mathrm{~Hz}, 1 \mathrm{H}) .{ }^{13} \mathrm{C} \mathrm{NMR}\left(100 \mathrm{MHz}, \mathrm{CD}_{2} \mathrm{Cl}_{2}\right)$ $\delta=108.4,108.6,113.2,142.6,143.4,156.0$. MS (ESITOF): $m / z(\%): 275.0[\mathrm{M}+\mathrm{H}]^{+}(100)$. HRMS-ESI-TOF $m / z$ calculated for $\mathrm{C}_{12} \mathrm{H}_{7} \mathrm{~N}_{2} \mathrm{O}_{2} \mathrm{~S}_{2}\left[\mathrm{M}+\mathrm{Na}^{+}\right.$: 274.994; found: 274.994.

4,6-di(thiazol-2-yl)-[3,4-c][1,2,5]thiadiazole (T-TTD-T). Obtained as a purple solid in $15 \%$ yield. ${ }^{1} \mathrm{H}$ NMR $(300 \mathrm{MHz}$, $\left.\mathrm{CD}_{2} \mathrm{Cl}_{2}\right) \delta=7.52(\mathrm{~d}, J=3.3 \mathrm{~Hz}, 1 \mathrm{H}), 7.88(\mathrm{~d}, J=3.0 \mathrm{~Hz}$, 1H). ${ }^{13} \mathrm{C}$ NMR $\left(101 \mathrm{MHz}, \mathrm{CD}_{2} \mathrm{Cl}_{2}\right) \delta=116.8,121.2,144.3$, 157.5, 158.6. MS (ESI-TOF): $\mathrm{m} / z(\%): 287.1[\mathrm{M}+\mathrm{Na}]^{+}(100)$. HRMS-ESI-TOF $m / z$ calculated for $\mathrm{C}_{10} \mathrm{H}_{4} \mathrm{~N}_{4} \mathrm{NaS}_{4}[\mathrm{M}+\mathrm{Na}]^{+}$: 287.1041; found: 287.1053 .

\section{B. Instrumentation}

\section{Absorption spectroscopy}

Solution UV-visible spectra were recorded, in methylene chloride solution $\left(10^{-5} \mathrm{M}\right)$, using a Shimadzu UV-2600 dualbeam spectrophotometer with a $1 \mathrm{~cm}$ quartz cell.

\section{Cyclic voltammetry}

Electrochemical measurements. Oxidation and reduction potentials were determined by cyclic voltammetry (CV) with a conventional 3-electrode system using a voltammetry analyzer equipped with a platinum micro-disk $\left(2 \mathrm{~mm}^{2}\right)$ working electrode and a platinum wire counter electrode. Potentials were calibrated versus the saturated calomel electrode (SCE), using the ferrocene/ferrocinium $\left(\mathrm{Fc} / \mathrm{Fc}^{+}\right)$couple as an internal reference and a conventional scan rate of $100 \mathrm{mV} / \mathrm{s}$. The oxidation potential $\left(E^{o x}\right)$ of $\mathrm{Fc} / \mathrm{Fc}^{+}$couple was $0.53 \mathrm{~V}$ versus SCE. The recrystallized tetrabutylammonium hexafluorophosphate $\left(\mathrm{Bu}_{4} \mathrm{NPF}_{6}\right)$ was used as the supporting electrolyte $(0.1 \mathrm{M})$ in distilled and anhydrous dichloromethane. Dichloromethane was distilled from $\mathrm{CaH}_{2}$ under a nitrogen atmosphere.

\section{Theoretical calculations}

All calculations of the model compounds studied in this work have been performed using the Gaussian 09 software package. ${ }^{43}$ The ground-state geometry of each model compound has been determined by a full geometry optimization of its structural parameters using density functional theory (DFT), upon energy minimization of all possible isomers, whereas the time-dependent density functional theory (TDDFT) calculations have been performed on the optimized structures. All calculations were performed in vacuum. No symmetry constraints were imposed during the optimization process. The geometry optimizations have been performed with a tight threshold that corresponds to root mean square (rms) residual forces smaller than $10^{-5}$ a.u. for the optimal geometry. The TD-DFT calculations were done using the same basis sets as those used in the ground-state DFT calculations. The energy level of the HOMO and the LUMO of the DAD small molecules was carried out by using the same set of calculations.

\section{RESULTS AND DISCUSSION}

\section{A. Synthesis}

All molecules have been synthesized following the same strategy of using a cross-coupling Stille reaction between 1 equivalent of the dibromo electron-withdrawing (A) units (BTD, PTD, and TTD) and 2.5 equivalents of 
the mono-stannyl electron-donating (D) units (i.e., T, F, and $\mathrm{Tz})$. The reactions were all carried out in toluene solution using standard tris(dibenzylideneacetone)dipalladium $(0)$ $\left[\mathrm{Pd}_{2}\left(\mathrm{dba}_{3}\right)\right]$ and tri $(o$-tolyl $)$ phosphine $\left[\mathrm{P}(o \text {-tol })_{3}\right]$ as a catalytic system. However, in the case of the electron withdrawing TTDbased unit, the Stille coupling has been performed prior to the ring cyclization due to the low stability of the dibromo TTD derivative in the Stille conditions, as shown in Fig. 1.

\section{B. Optical properties}

The absorption spectra in dichloromethane solution of the DAD small molecules when the electron donating (D) unit remains constant and alters the electron deficient (A) unit are presented in Fig. 2. It is shown that the absorption spectra of the DAD monomers are qualitatively the same. Two absorption peak maxima are spotted, a common characteristic when D and A components are hybridized. ${ }^{36}$ The low-wavelength absorption maxima have been assigned to a $\pi-\pi^{*}$ electronic excitation, whereas the high-wavelength absorption maxima have been attributed to an intramolecular D-A charge transfer. ${ }^{44}$

\section{Influence of the electron deficient $(A)$ unit on the absorption maxima and bandgap of DAD small molecules}

The $\lambda_{\max }$ of T-BTD-T, T-PTD-T, and T-TTD-T are $447 \mathrm{~nm}, 465 \mathrm{~nm}$, and $626 \mathrm{~nm}$, respectively (Fig. 2, top); those of F-BTD-F, F-PTD-F, and F-TTD-F are $453 \mathrm{~nm}, 468 \mathrm{~nm}$, and $626 \mathrm{~nm}$, respectively (Fig. 2, middle), and finally the $\lambda_{\max }$ of Tz-BTD-Tz, Tz-PTD-Tz, and Tz-TTD-Tz are $431 \mathrm{~nm}$, $437 \mathrm{~nm}$, and $580 \mathrm{~nm}$, respectively (Fig. 2, bottom). In addition, the optical bandgap $\left(E_{g}{ }^{o p t}\right)$, as estimated from the $1240 / \lambda^{\text {onset }}$ $(\mathrm{eV})$ where $\lambda^{\text {onset }}$ is the wavelength absorption onset, of TBTD-T, T-PTD-T, and T-TTD-T are $2.43 \mathrm{eV}, 2.31 \mathrm{eV}$, and $1.71 \mathrm{eV}$, respectively (Fig. 2, top). Moreover, the $E_{g}{ }^{\text {opt }}$ of FBTD-F, F-PTD-F, and F-TTD-F are $2.41 \mathrm{eV}, 2.31 \mathrm{eV}$, and 1.73 $\mathrm{eV}$, respectively (Fig. 2, middle) and finally the $E_{g}{ }^{\text {opt }}$ of TzBTD-Tz, Tz-PTD-Tz, and Tz-TTD-Tz are $2.56 \mathrm{eV}, 2.49 \mathrm{eV}$, and $1.89 \mathrm{eV}$, respectively (Fig. 2, bottom). In general, it can be concluded that maintaining the D unit (furan, thiophene, or thiazole) constant, the $\lambda_{\max }$ of the BTD, PTD, or TTD-based DAD small molecules is red shifted when passing from BTD to PTD and then to TTD, while the $E_{g}{ }^{\text {opt }}$ is lowered.

\section{Influence of the electron donating (D) unit on the absorption maxima and bandgap of DAD triads}

The absorption spectra of the DAD small molecules when the $\mathrm{A}$ unit remains constant and alters the $\mathrm{D}$ unit are presented in Fig. S1. The $\lambda_{\max }$ of Tz-BTD-Tz, T-BTD-T, and F-BTD-F are $431 \mathrm{~nm}, 447 \mathrm{~nm}$, and $453 \mathrm{~nm}$, respectively (Fig. S1, top); those of Tz-PTD-Tz, T-PTD-T, and F-PTD-F are $437 \mathrm{~nm}, 465$ $\mathrm{nm}$, and $468 \mathrm{~nm}$, respectively (Fig. S1, middle); and finally the $\lambda_{\max }$ of Tz-TTD-Tz, T-TTD-T, and F-TTD-F are $580 \mathrm{~nm}$, $626 \mathrm{~nm}$, and $626 \mathrm{~nm}$, respectively (Fig. S1, bottom). In addition, the $E_{g}{ }^{o p t}$ of Tz-BTD-Tz, T-BTD-T, and F-BTD-F are 2.56 $\mathrm{eV}, 2.43 \mathrm{eV}$, and $2.41 \mathrm{eV}$, respectively (Fig. S1, top); those of Tz-PTD-Tz, T-PTD-T, and F-PTD-F are $2.49 \mathrm{eV}, 2.31 \mathrm{eV}$, and $2.31 \mathrm{eV}$, respectively (Fig. S1, middle); and finally the $E_{g}{ }^{\text {opt }}$ of Tz-TTD-Tz, T-TTD-T, and F-TTD-F are $1.89 \mathrm{eV}, 1.71 \mathrm{eV}$, and $1.73 \mathrm{eV}$, respectively (Fig. S1, bottom). In general, it can
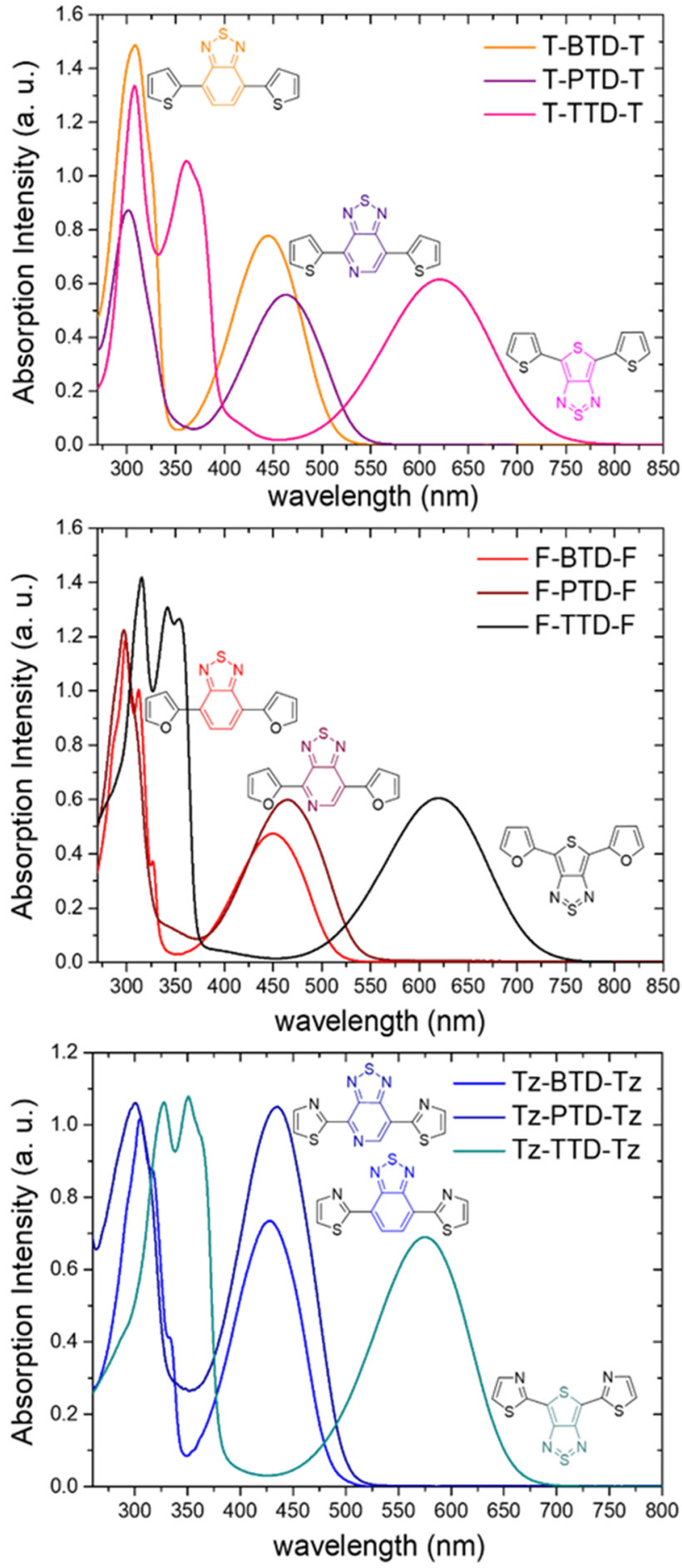

FIG. 2. Absorption spectra in $\mathrm{CH}_{2} \mathrm{Cl}_{2}$ solution of the DAD monomers, while the $\mathrm{D}$ unit remains constant and alters the $\mathrm{A}$ unit.

be concluded that in all cases the furan and thiophene-based DAD small molecules have similar $E_{g}{ }^{o p t}$, while the $E_{g}{ }^{\text {opt }}$ of the thiazole-based DAD small molecules are higher as compared to furan and thiophene counterparts. This suggests that, for a constant A unit, the introduction of a weak D in the DAD triad leads to higher bandgap materials. For the $\lambda_{\max }$, it is shown that the $\lambda_{\max }$ of the furan or thiophene-based DAD triads are situated at higher wavelengths as compared to thiazole-based DAD small molecules, with the $\lambda_{\max }$ of the furan-based DAD triads to be slightly red shifted as compared to thiophene-based 
DAD small molecules, except in the case where the TTD is used as A.

\section{Correlation between the experimental optical properties of DAD triads with their theoretical values}

Theoretical calculations via density functional theory (DFT) using the B3LYP/6-311G(d,p), B3PW91/6-311G(d,p), and HSEH1PBE/6-311G(2d,2p) as well as time-dependent density functional theory (TD-DFT) using the B3LYP/6311G(d,p) and B3PW91/6-311G(d,p) have been performed on the 9 DAD molecules, and the results are presented in Table I. In Table I, the values of the experimental $E_{g}{ }^{\text {opt }}$, electrochemical bandgap $\left(E_{g}{ }^{\text {elect }}\right)$, and energy bandgap at the maximum absorption $\left(\lambda_{\max }\right)$ are also presented.

Among all the theoretical models employed, it is observed that the energy bandgap as calculated by DFT (HSEH1PBE/6$311 \mathrm{G}(2 \mathrm{~d}, 2 \mathrm{p})$ ) and TD-DFT (B3PW91/6-311G(d,p)) is in very good agreement with the $E_{g}{ }^{o p t}$ of the DAD molecules. In Fig. 3, the experimental $E_{g}{ }^{o p t}$ is plotted versus the energy bandgap as obtained by the DFT (HSEH1PBE/6-311G(2d,2p)) and the TD-DFT (B3PW91/6-311G(d,p)). In particular, Eq. (1) provides the linear relationship between the experimental $E_{g}{ }^{o p t}$ and the energy bandgap as obtained by the DFT (HSEH1PBE/6-311G(2d,2p)),

$$
\mathrm{E}_{\mathrm{g}}{ }^{\text {opt }}=0.95 \times \mathrm{E}_{\mathrm{g}}^{\mathrm{DFT}}+0.15,
$$

and Eq. (2) provides the linear relationship between the experimental $E_{g}{ }^{\text {opt }}$ and the energy bandgap as obtained by the TD-DFT (B3PW91/6-311G(d,p)),

$$
\mathrm{E}_{\mathrm{g}}{ }^{\text {opt }}=1.03 \times \mathrm{E}_{\mathrm{g}}^{\mathrm{TD}-\mathrm{DFT}}-0.07,
$$

while all employed adjusted $\mathrm{r}$ squared $\left(\mathrm{R}^{2}\right)$ interpretation values were above 0.99 , indicative of excellent quality fittings.

However, the most interesting outcome is that the $\lambda_{\max }$ wavelengths of the DAD monomers can be predicted in very high accuracy from the DFT calculations based on the B3LYP/6-311G(d,p) and B3PW91/6-311G(d,p), instead of the HSEH1PBE/6-311G(2d,2p), as can be seen in Table I and Fig. 4. In Fig. 4, the experimental $\lambda_{\max }$ is plotted versus the energy bandgap as obtained by the DFT [B3LYP/6$311 \mathrm{G}(\mathrm{d}, \mathrm{p})$ and B3PW91/6-311G(d,p)] calculations. In particular, Eqs. (3) and (4) provide the linear relationship between

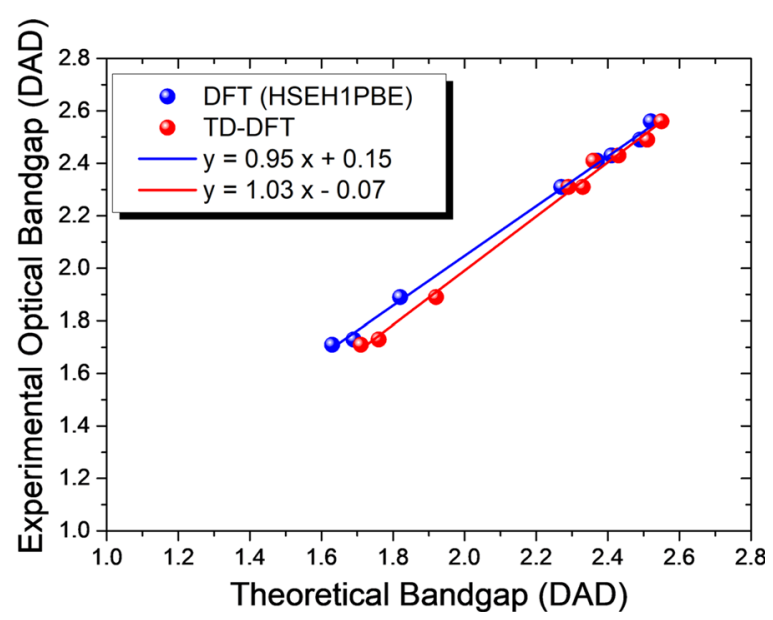

FIG. 3. Experimental $E_{g}{ }^{\text {opt }}$ versus the energy bandgap as obtained by the DFT (HSEH1PBE/6-311G(2d,2p)) and the TD-DFT (B3PW91/6-311G(d,p)).

the experimental $\lambda_{\max }$ and the energy bandgap as obtained by the B3LYP/6-311G(d,p) [Eq. (3)] and B3PW91/6-311G(d,p) [Eq. (4)], respectively,

$$
\begin{aligned}
& \lambda_{\text {max }}=0.94 \times \mathrm{E}_{\mathrm{g}}^{\mathrm{DFT}}+0.13, \\
& \lambda_{\text {max }}=0.95 \times \mathrm{E}_{\mathrm{g}}^{\mathrm{DFT}}+0.18,
\end{aligned}
$$

while all employed $\mathrm{R}^{2}$ interpretation values were above 0.99 , indicative of excellent quality fittings. To the best of our knowledge, it is demonstrated for the first time that the bandgaps estimated by DFT calculations based on the B3LYP/6-311G(d,p) and B3PW91/6-311G $(\mathrm{d}, \mathrm{p})$ are correlated in very high accuracy with the $\lambda_{\max }$ of the DAD monomers.

\section{Electrochemical properties}

In order to estimate the energy levels of the DAD molecules and as a consequence the $E_{g}{ }^{\text {elect }}$, cyclic voltammetry (CV) was performed. The oxidation and reduction potentials of the studied DAD triads are shown in Fig. 5.

It is presented that all the DAD systems exhibit irreversible oxidation (the top scheme of Fig. 5) and reversible reduction (the bottom scheme of Fig. 5) peaks. For the reversible reduc-

\begin{tabular}{|c|c|c|c|c|c|c|c|c|}
\hline & \multicolumn{3}{|c|}{$\begin{array}{c}\text { Bandgap (eV) } \\
\text { (DFT) }\end{array}$} & \multicolumn{2}{|c|}{$\begin{array}{c}\text { Bandgap (eV) } \\
\text { (TD-DFT) }\end{array}$} & \multicolumn{3}{|c|}{$\begin{array}{l}\text { Experimental } \\
\text { bandgap }(\mathrm{eV})\end{array}$} \\
\hline & $\begin{array}{c}\text { B3LYP/ } \\
\text { 6-311G(d,p) }\end{array}$ & $\begin{array}{c}\text { B3PW91/ } \\
\text { 6-311G(d,p) }\end{array}$ & $\begin{array}{l}\text { HSEH1PBE/ } \\
6-311 G(2 d, 2 p)\end{array}$ & $\begin{array}{c}\text { B3LYP/ } \\
\text { 6-311G(d,p) }\end{array}$ & $\begin{array}{c}\text { B3PW91/ } \\
\text { 6-311G(d,p) }\end{array}$ & $E_{g}{ }^{o p t}$ & $E_{g}$ elect & $\lambda_{\max }$ \\
\hline F-BTD-F & 2.74 & 2.77 & 2.37 & 2.32 & 2.36 & 2.41 & 2.35 & 2.74 \\
\hline T-BTD-T & 2.84 & 2.86 & 2.41 & 2.40 & 2.43 & 2.43 & 2.47 & 2.77 \\
\hline Tz-BTD-Tz & 2.91 & 2.94 & 2.52 & 2.51 & 2.55 & 2.56 & 2.75 & 2.88 \\
\hline F-PTD-F & 2.66 & 2.69 & 2.27 & 2.26 & 2.29 & 2.31 & 2.26 & 2.65 \\
\hline T-PTD-T & 2.70 & 2.73 & 2.29 & 2.29 & 2.33 & 2.31 & 2.31 & 2.67 \\
\hline Tz-PTD-Tz & 2.86 & 2.88 & 2.49 & 2.48 & 2.51 & 2.49 & 2.54 & 2.84 \\
\hline F-TTD-F & 1.98 & 2.05 & 1.69 & 1.70 & 1.76 & 1.73 & 1.70 & 1.98 \\
\hline T-TTD-T & 1.94 & 2.01 & 1.63 & 1.64 & 1.71 & 1.71 & 1.78 & 1.98 \\
\hline Tz-TTD-Tz & 2.14 & 2.21 & 1.82 & 1.86 & 1.92 & 1.89 & 1.86 & 2.14 \\
\hline
\end{tabular}
tion peaks, the reduction potential $\left(E^{\text {red }}\right)$ is calculated by $\left[\left(\mathrm{E}_{\mathrm{p}, \mathrm{c}}\right.\right.$ $\left.\left.+\mathrm{E}_{\mathrm{p}, \mathrm{a}}\right) / 2\right]$, where $\mathrm{E}_{\mathrm{p}, \mathrm{c}}$ and $\mathrm{E}_{\mathrm{p}, \mathrm{a}}$ are the cathodic and anodic peak

TABLE I. Theoretical (DFT, TD-DFT) calculations and experimental (optical, electrochemical, and maximum absorption) bandgaps of the studied molecules. 


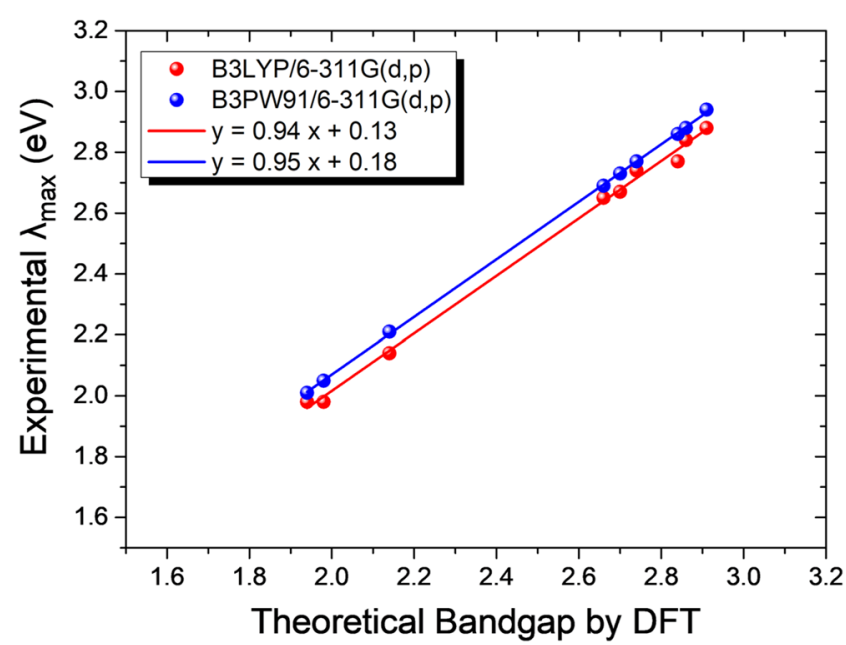

FIG. 4. Experimental $\lambda_{\max }$ versus the energy bandgap as obtained by the DFT [B3LYP/6-311G(d,p) and B3PW91/6-311G(d,p)] calculations.

potentials, respectively. Additionally, for the irreversible oxidation peaks, the oxidation potential $\left(E^{o x}\right)$ is calculated from the onset of the oxidation peak (dashed lines in the top scheme of Fig. 5). The corresponding $E_{H O M O}$ and $E_{L U M O}$ were calculated using the formulae $E_{\text {HOMO }}=-\left(E^{o x}+5.1\right) \mathrm{eV}$ and $E_{L U M O}=-\left(E^{r e d}+5.1\right) \mathrm{eV},{ }^{45}$ respectively, and their values are summarized in Table II.

\section{Influence of the electron deficient $(A)$ unit on the energy levels of DAD small molecules}

By keeping the D unit (thiophene) constant, replacing the BTD with PTD, the $E_{\text {Номо }}$ is slightly shifted to deeper values versus vacuum as compared to the significantly larger shift of the $E_{L U M O}$ level, establishing that PTD is a stronger electron withdrawing unit than BTD. As a consequence, the $E_{g}{ }^{\text {elect }}$ is significantly reduced (Fig. 6). Moreover, by replacing the PTD with TTD, the $E_{L U M O}$ level is slightly shifted to a deeper value (in agreement with the theoretical results), demonstrating that the TTD-based small molecules exhibit higher electron affinities than the PTD-based analogs. On the contrary, the $E_{\text {Номо }}$ level is upshifted due to the electron donating character of the thiophene ring of the TTD unit as compared to the pyridine
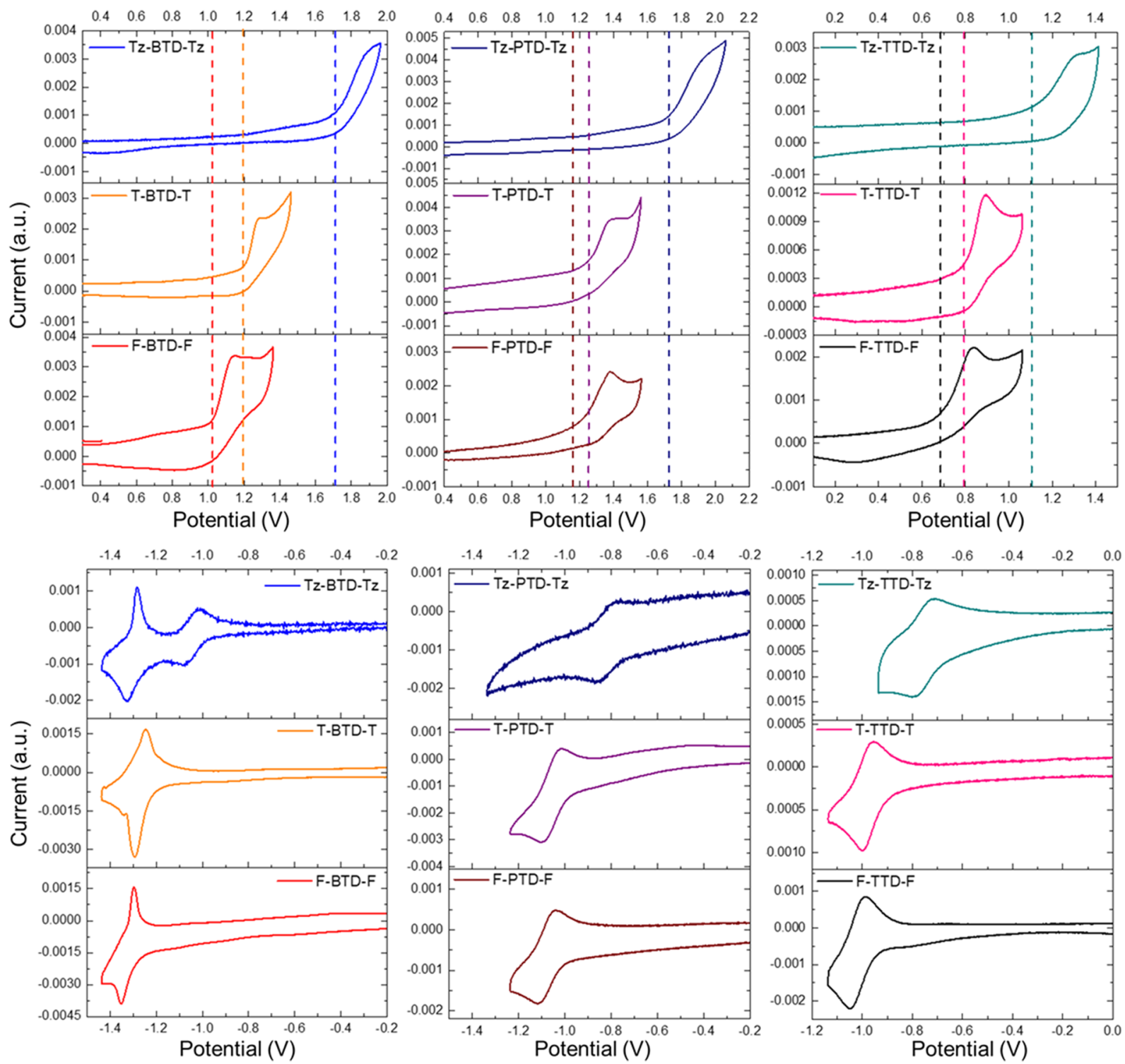

FIG. 5. Cyclic voltammetry graphs of the DAD molecules during oxidation (top) and reduction (bottom) processes. 
TABLE II. Experimental energy levels as obtained by cyclic voltammetry and theoretical energy levels as estimated by DFT [B3LYP/6-311G(d,p), B3PW91/6$311 \mathrm{G}(\mathrm{d}, \mathrm{p})$, and HSEH1PBE/6-311G(2d,2p)] calculations.

\begin{tabular}{|c|c|c|c|c|c|c|c|c|c|c|c|c|}
\hline & \multicolumn{3}{|c|}{$\begin{array}{c}\text { B3LYP/ } \\
6-311 \mathrm{G}(\mathrm{d}, \mathrm{p})(\mathrm{eV})\end{array}$} & \multicolumn{3}{|c|}{$\begin{array}{c}\text { B3PW91/ } \\
\text { 6-311G(d,p) (eV) }\end{array}$} & \multicolumn{3}{|c|}{$\begin{array}{c}\text { HSEH1PBE/ } \\
\text { 6-311G(2d,2p) (eV) }\end{array}$} & \multicolumn{3}{|c|}{ Experimental $(\mathrm{eV})$} \\
\hline & HOMO & LUMO & Gap & HOMO & LUMO & Gap & HOMO & LUMO & Gap & HOMO & LUMO & Bandgap \\
\hline F-BTD-F & 5.55 & 2.81 & 2.74 & 5.63 & 2.86 & 2.77 & 5.21 & 2.84 & 2.37 & -5.59 & -3.24 & 2.35 \\
\hline T-BTD-T & 5.69 & 2.85 & 2.84 & 5.77 & 2.91 & 2.86 & 5.38 & 2.97 & 2.41 & -5.76 & -3.29 & 2.47 \\
\hline Tz-BTD-Tz & 6.07 & 3.16 & 2.91 & 6.16 & 3.22 & 2.94 & 5.78 & 3.26 & 2.52 & -6.27 & -3.52 & 2.75 \\
\hline F-PTD-F & 5.74 & 3.08 & 2.66 & 5.82 & 3.13 & 2.69 & 5.40 & 3.14 & 2.27 & -5.75 & -3.49 & 2.26 \\
\hline T-PTD-T & 5.84 & 3.14 & 2.70 & 5.93 & 3.20 & 2.73 & 5.54 & 3.25 & 2.29 & -5.82 & -3.51 & 2.31 \\
\hline Tz-PTD-Tz & 6.26 & 3.40 & 2.86 & 6.34 & 3.46 & 2.88 & 5.96 & 3.47 & 2.49 & -6.29 & -3.75 & 2.54 \\
\hline F-TTD-F & 5.13 & 3.15 & 1.98 & 5.22 & 3.17 & 2.05 & 4.84 & 3.15 & 1.69 & -5.25 & -3.55 & 1.70 \\
\hline T-TTD-T & 5.20 & 3.26 & 1.94 & 5.29 & 3.28 & 2.01 & 4.95 & 3.31 & 1.63 & -5.37 & -3.59 & 1.78 \\
\hline Tz-TTD-Tz & 5.67 & 3.53 & 2.14 & 5.76 & 3.55 & 2.21 & 5.40 & 3.58 & 1.82 & -5.67 & -3.81 & 1.86 \\
\hline
\end{tabular}

ring of the PTD unit. Finally, the $E_{g}{ }^{\text {elect }}$ is further lowered. The above experimental findings are also supported by the fact that if the $\mathrm{D}$ unit is replaced with other electron-donating moieties of various strengths like furan or thiazole, the energy levels follow similar trends (Fig. 6).

\section{Influence of the electron donating (D) unit on the energy levels of DAD triads}

By keeping the A unit (BTD) constant, the $E_{L U M O}$ level of the DAD triads consisting of furan and thiophene rings
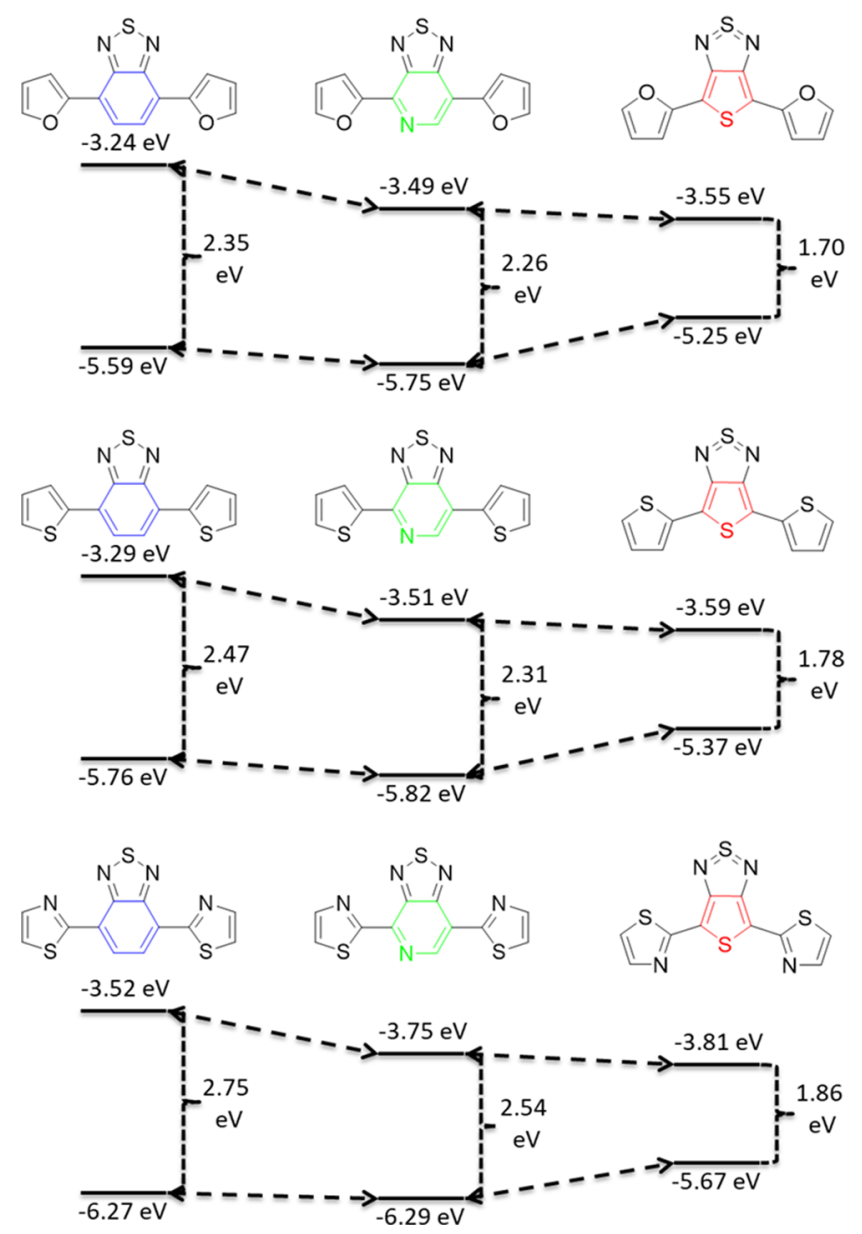

FIG. 6. Schematic representation of the energy level alignment for the studied DAD small molecules when the $\mathrm{D}$ unit is unchanged. remains almost unaltered; however, the $E_{\text {НОМO }}$ of the furanbased triad is upshifted by $0.1 \mathrm{eV}$ versus vacuum indicating that furan is a stronger electron donating unit than thiophene (Fig. S2). In addition, the $E_{g}{ }^{\text {elect }}$ is not significantly altered. On the other hand, both the $E_{H O M O}$ and $E_{L U M O}$ levels of the thiadiazole-based triad are shifted to deeper values (a result that is consistent with the theoretical values) versus vacuum demonstrating that thiazole is a weaker electron donating unit than furan or thiophene, whereas the $E_{g}$ elect is higher as compared to the related furan and thiophene derivatives. Based on the above results, the strength of the electron donating unit follows this order: furan $>$ thiophene $>$ thiazole. The above experimental findings are also supported by the fact that if the A unit is replaced with other electron-deficient moieties like the PTD or TTD, the energy levels follow similar trends (Fig. $\mathrm{S} 2)$.

\section{Correlation between the experimental energy levels of the DAD triads with their theoretical values}

The theoretical energy levels as calculated by DFT using the three different models [B3LYP/6-311G(d,p), B3PW91/6$311 \mathrm{G}(\mathrm{d}, \mathrm{p})$, and HSEH1PBE/6-311G $(2 \mathrm{~d}, 2 \mathrm{p})]$ are presented in Table II. It is shown that the $E_{\text {НОмO }}$ levels as estimated by B3PW91/6-311G(d,p) demonstrate higher accuracy to the experimental results as compared to the results obtained by B3LYP/6-311G(d,p) and HSEH1PBE/6-311G(2d,2p). On the contrary, the theoretical $E_{L U M O}$ levels, as estimated using all the three models [B3LYP/6-311G(d,p), B3PW91/6$311 \mathrm{G}(\mathrm{d}, \mathrm{p})$, and HSEH1PBE/6-311G(2d,2p)], derogate significantly from the experimental results. In order to increase the accuracy between the experimental and theoretical $E_{L U M O}$ levels, the theoretical $E_{L U M O}$ levels were derived by the difference between the theoretical $E_{\text {HOMO }}$ values from DFT (B3PW91/6$311 \mathrm{G}(\mathrm{d}, \mathrm{p}))$ and the $E_{g}{ }^{\text {opt }}$ values from DFT (HSEH1PBE/6$311 \mathrm{G}(2 \mathrm{~d}, 2 \mathrm{p})$ ) or the TD-DFT (B3PW91/6-311G(d,p)) of Table I. A schematic representation of the energy level alignment of all the studied DAD triads has been prepared including the experimental values (black lines) and the theoretical $E_{H O M O}$ and $E_{L U M O}$ values as estimated by DFT (B3PW91/6$311 \mathrm{G}(\mathrm{d}, \mathrm{p}))$ (green lines) and subtracting the $E_{g}{ }^{\text {opt }}$ values of the DFT (HSEH1PBE/6-311G(2d,2p)) (red line) (Fig. 7) or the TD-DFT (B3PW91/6-311G(d,p)) (red line) (Fig. S3) from the 


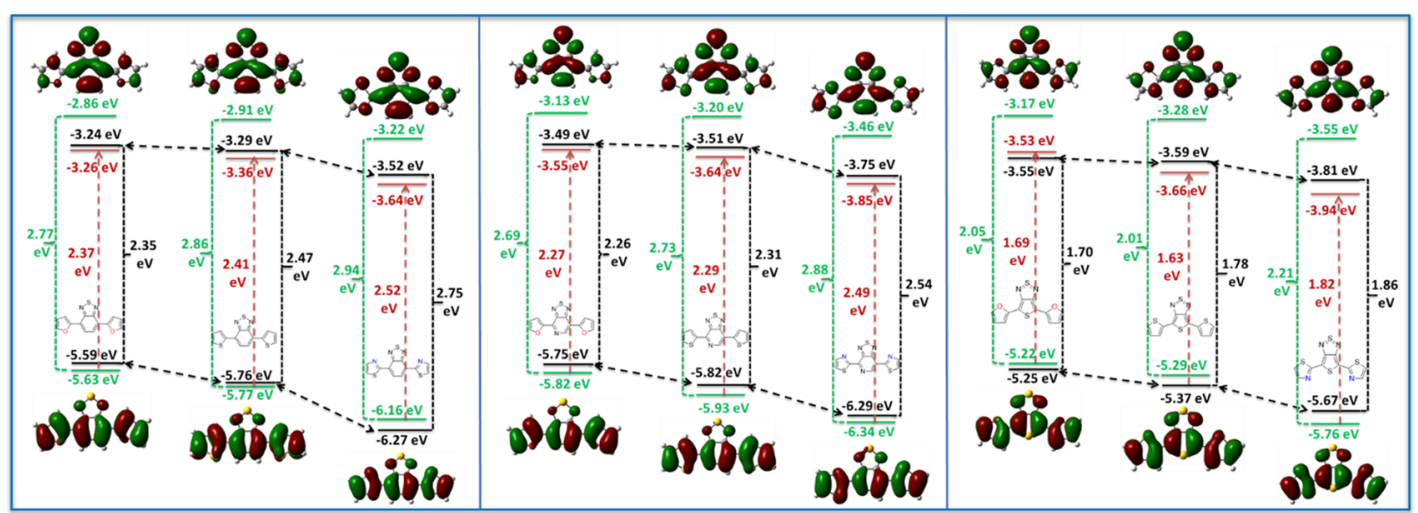

FIG. 7. Schematic representation of the energy levels of all the studied DAD triads including the experimental values (black lines) and the theoretical values as calculated by DFT (B3PW91/6-311G(d,p)) (green lines) and the DFT (HSEH1PBE/6-311G(2d,2p)) (red line) $E_{g}{ }^{\text {opt }}$ values.

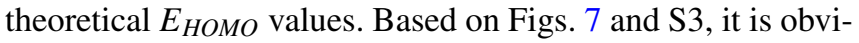
ous that the theoretical $E_{L U M O}$ levels by subtracting the $E_{g}{ }^{\text {opt }}$ values of the DFT (HSEH1PBE/6-311G(2d,2p)) from the theoretical $E_{\text {Номо }}$ values as estimated by DFT (B3PW91/6$311 \mathrm{G}(\mathrm{d}, \mathrm{p}))$ are in higher accuracy with the experimental $E_{\text {LUMO }}$ values (Fig. 7).

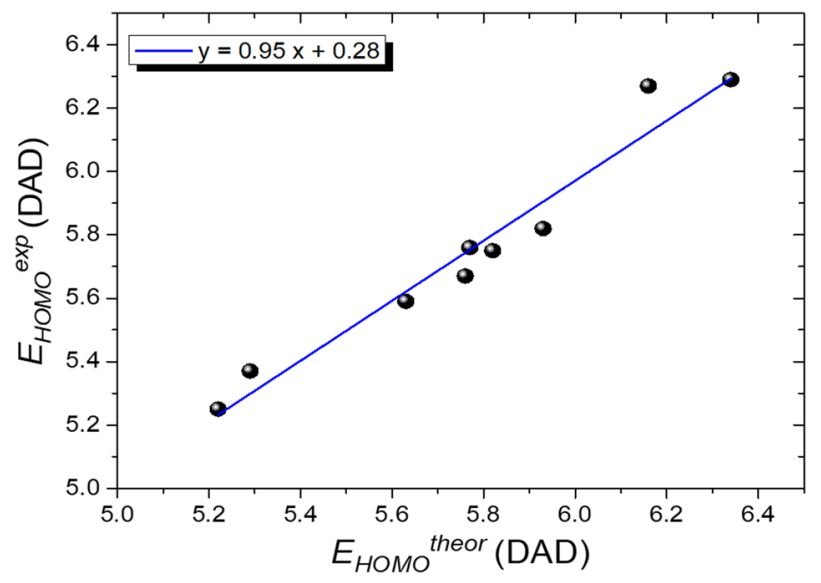

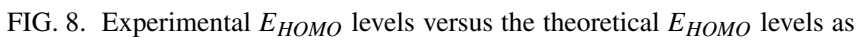
obtained by the DFT (B3PW91/6-311G(d,p)).

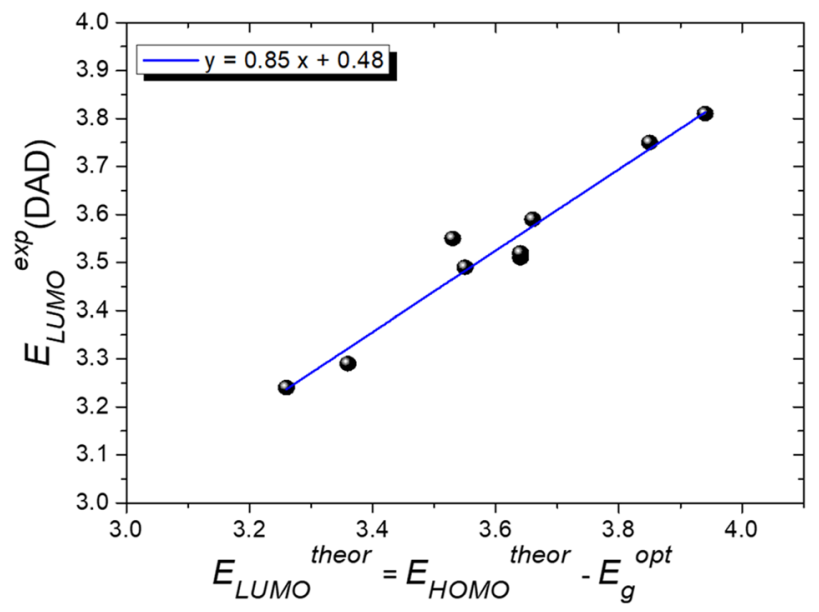

FIG. 9. Experimental $E_{L U M O}$ values versus the theoretical $E_{L U M O}$ values as determined from the theoretical $E_{\text {HOMO }}$ values minus the $E_{g}{ }^{o p t}$ values from DFT (HSEH1PBE/6-311G(2d,2p)).

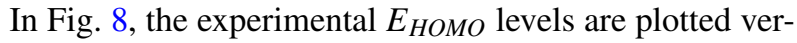
sus the theoretical $E_{\text {НОмо }}$ levels as obtained by the DFT (B3PW91/6-311G(d,p)) (Table II). In particular, Eq. (5) provides the linear relationship between the experimental $E_{\text {Номо }}$ level and the theoretical,

$$
E_{\text {НОМO }}{ }^{\exp }=0.95 \times E_{\text {НОМO }}{ }^{\text {theor }}+0.28,
$$

while all employed $R^{2}$ interpretation values were above 0.95 , indicative of excellent quality fittings.

Furthermore, the experimental $E_{L U M O}$ values are plotted versus the theoretical $E_{L U M O}$ values as determined from the theoretical $E_{\text {HOMO }}$ values from DFT (B3PW91/6$311 \mathrm{G}(\mathrm{d}, \mathrm{p}))$ minus the $E_{g}{ }^{\text {opt }}$ values from DFT (HSEH1PBE/6$311 \mathrm{G}(2 \mathrm{~d}, 2 \mathrm{p}))$ (Fig. 9).

Equation (6) provides the linear relationship between the experimental $E_{L U M O}$ values and the theoretical,

$$
E_{L U M O}{ }^{\exp }=0.85 \times E_{L U M O}{ }^{\text {theor }}+0.48,
$$

while all employed $\mathrm{R}^{2}$ interpretation values were above 0.95 , indicative of excellent quality fittings.

\section{CONCLUSIONS}

It is reported the efficient synthesis of a series of DAD $\pi$ conjugated small molecules as model compounds containing thiazole, thiophene, and furan as the D unit and BTD, PTD, and TTD as the A moieties. Based on the experimental studies of their optical and electrochemical properties, it has been shown that for a constant A unit, the introduction of a weak D (the strength of the electron donating unit following this order: furan $>$ thiophene $>$ thiazole) in the DAD triad leads to higher bandgap materials. For the $\lambda_{\max }$, on the one hand, it is shown that the $\lambda_{\max }$ of the furan or thiophene-based DAD triads are situated at higher wavelengths as compared to thiazole-based DAD small molecules, with the $\lambda_{\max }$ of the furan-based DAD triads to be slightly red shifted as compared to thiophene-based DAD small molecules, except in the case where the TTD is used as A. On the other hand, maintaining the D unit (furan, thiophene, or thiazole) constant, the $\lambda_{\max }$ of the BTD, PTD, or TTD-based DAD small molecules is red shifted as passing from the BTD to PTD and then to TTD, while the $E_{g}{ }^{\text {opt }}$ is lowered. 
Among these theoretical models employed, it is observed that the energy bandgap as calculated by DFT (HSEH1PBE/6$311 \mathrm{G}(2 \mathrm{~d}, 2 \mathrm{p})$ ) and TD-DFT (B3PW91/6-311G(d,p)) is in very good agreement with the $E_{g}{ }^{\text {opt }}$ of the DAD small molecules. Furthermore, the $\lambda_{\max }$ wavelengths of the DAD monomers can be predicted with a high accuracy from the DFT calculations based on the B3LYP/6-311G(d,p) and B3PW91/6-311G(d,p), instead of the HSEH1PBE/6-311G(2d,2p). Finally, from the theoretical electrochemical studies performed, it is demonstrated that the $E_{\text {НОMO }}$ levels as estimated by B3PW91/6$311 \mathrm{G}(\mathrm{d}, \mathrm{p})$ demonstrate higher accuracy to the experimental results as compared to the results obtained by B3LYP/6$311 \mathrm{G}(\mathrm{d}, \mathrm{p})$ and HSEH1PBE/6-311G(2d,2p), whereas the theoretical $E_{L U M O}$ levels deduced by subtracting the $E_{g}{ }^{o p t}$ values of the DFT (HSEH1PBE/6-311G (2d,2p)) from the theoretical

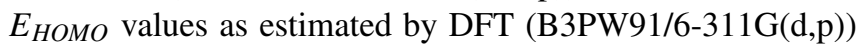
are in higher accuracy with the experimental $E_{L U M O}$ values. These observations lead to the establishment of 6 model equations predicting in prior to the optical and electrochemical properties of the DAD small molecules by simple quantum chemical calculations.

\section{SUPPLEMENTARY MATERIAL}

See supplementary material for the absorption spectra, energy levels alignment, and schematic representation of the energy levels of all the studied DAD triads.

\section{ACKNOWLEDGMENTS}

This project has received funding from the European Community's Seventh Framework Programme (No. FP7/2007-2013) under Grant Agreement Nos. 331389 project ECOCHEM and 604603 project MatHero. Dr. Boero and Dr. Chaker are kindly acknowledged for their useful comments on the manuscript.

${ }^{1}$ R. Farchioni and G. Grosso, Organic Electronic Materials: Conjugated Polymers and Low Molecular Weight Organic Solids (Springer, Berlin, 2001).

${ }^{2}$ L. S. Miller and J. B. Mullin, Electronic Materials : From Silicon to Organics (Plenum Press, New York, 1991).

${ }^{3}$ G. Yu, J. C. Hummelen, F. Wudl, and A. J. Heeger, Science 270, 1789 (1995).

${ }^{4}$ B. O'Regan and M. Grätzel, Nature 353, 737 (1991).

${ }^{5}$ J. Liu, H. Zhang, H. Dong, L. Meng, L. Jiang, L. Jiang, Y. Wang, J. Yu, Y. Sun, W. Hu, and A. J. Heeger, Nat. Commun. 6, 10032 (2015).

${ }^{6}$ J. H. Burroughes, D. D. C. Bradley, A. R. Brown, R. N. Marks, K. Mackay, R. H. Friend, P. L. Burn, and A. B. Holmes, Nature 347, 539 (1990).

${ }^{7}$ P. M. Beaujuge, S. Ellinger, and J. R. Reynolds, Nat. Mater. 7, 795 (2008).

${ }^{8}$ C. M. Benavides, P. Murto, C. L. Chochos, V. G. Gregoriou, A. Avgeropoulos, X. Xu, K. Bini, A. Sharma, M. R. Andersson, O. Schmidt, C. J. Brabec, E. Wang, and S. F. Tedde, ACS Appl. Mater. Interfaces 10, 12937 (2018).

${ }^{9}$ K. Müllen and W. Pisula, J. Am. Chem. Soc. 137, 9503 (2015).

${ }^{10}$ J. E. Anthony, Angew. Chem., Int. Ed. 47, 452 (2008).

${ }^{11}$ D. A. da Silva Filho, E. G. Kim, and J. L. Brédas, Adv. Mater. 17, 1072 (2005).

${ }^{12}$ A. Katsouras, N. Gasparini, C. Koulogiannis, M. Spanos, T. Ameri, C. J. Brabec, C. L. Chochos, and A. Avgeropoulos, Macromol. Rapid Commun. 36, 1778 (2015).
${ }^{13}$ D. G. Patel, Y. Y. Ohnishi, Y. X. Yang, S. H. Eom, R. T. Farley, K. R. Graham, J. G. Xue, S. Hirata, K. S. Schanze, and J. R. Reynolds, J. Polym. Sci., Part B: Polym. Phys. 49, 557 (2011).

${ }^{14}$ Y. Yang, Q. Pei, and A. J. Heeger, J. Appl. Phys. 79, 934 (1996).

${ }^{15}$ J. Roncali, P. Leriche, and A. Cravino, Adv. Mater. 19, 2045 (2007).

${ }^{16}$ C. J. Kudla, D. Dolfen, K. J. Schottler, J.-M. Koenen, D. Breusov, S. Allard, and U. Scherf, Macromolecules 43, 7864 (2010).

${ }^{17}$ L. Dalton, P. Sullivan, and D. H. Bale, Chem. Rev. 110, 25 (2010).

${ }^{18}$ Q. Chen, E. H. Sargent, N. Leclerc, and A.-J. Attias, Appl. Phys. Lett. 82, 4420 (2003).

${ }^{19}$ Q. Chen, E. H. Sargent, N. Leclerc, and A.-J. Attias, Appl. Opt. 42, 7235 (2003).

${ }^{20}$ M. Rumi, S. Barlow, J. Wang, J. Perry, and S. R. Marder, Adv. Polym. Sci. 213, 1 (2008).

${ }^{21}$ M. Pawlicki, H. A. Collins, R. G. Denning, and H. L. Anderson, Angew. Chem., Int. Ed. 48, 3244 (2009).

${ }^{22}$ P. M. Beaujuge, H. N. Tsao, M. R. Hansen, C. M. Amb, C. Risko, J. Subbiah, K. R. Choudhury, A. Mavrinskiy, W. Pisula, J.-L. Brédas, F. So, K. Müllen, and J. R. Reynolds, J. Am. Chem. Soc. 134, 8944 (2012).

${ }^{23}$ C. M. Amb, A. L. Dyer, and J. R. Reynolds, Chem. Mater. 23, 397 (2010).

${ }^{24}$ P. M. Beaujuge, C. M. Amb, and J. R. Reynolds, Acc. Chem. Res. 43, 1396 (2010).

${ }^{25}$ P. M. Beaujuge and J. R. Reynolds, Chem. Rev. 110, 268 (2010).

${ }^{26}$ Y. Wu and W. Zhu, Chem. Soc. Rev. 42, 2039 (2013).

${ }^{27}$ C. Qin, A. Mirloup, N. Leclerc, A. Islam, A. El-Shafei, L. Han, and R. Ziessel, Adv. Energy Mater. 4, 1400085 (2014).

${ }^{28}$ A. Mishra, M. K. R. Fischer, and P. Bauerle, Angew. Chem., Int. Ed. 48, 2474 (2009).

${ }^{29}$ C. A. Richard, Z. Pan, H. Y. Hsu, S. Cekli, K. S. Schanze, and J. R. Reynolds, ACS Appl. Mater. Interfaces 6, 5221 (2014).

${ }^{30}$ A. C. Grimsdale, K. L. Chan, R. E. Martin, P. G. Jokisz, and A. B. Holmes, Chem. Rev. 109, 897 (2009).

${ }^{31}$ Y. Lin, Y. Li, and X. Zhan, Chem. Soc. Rev. 41, 4245 (2012).

${ }^{32}$ I. Bulut, P. Chávez, A. Mirloup, Q. Huaulmé, B. Heinrich, A. Hébraud, S. Méry, R. Ziessel, T. Heiser, P. Lévêque, and N. Leclerc, J. Mater. Chem. C 4, 4296 (2016).

${ }^{33}$ J. E. Anthony, Chem. Mater. 23, 583 (2011).

${ }^{34}$ L. Bian, E. Zhu, J. Tang, W. Tang, and F. Zhang, Prog. Polym. Sci. 37, 1292 (2012).

${ }^{35}$ Y.-J. Cheng, S.-H. Yang, and C.-S. Hsu, Chem. Rev. 109, 5868 (2009).

${ }^{36}$ C. L. Chochos and S. A. Choulis, Prog. Polym. Sci. 36, 1326 (2011).

${ }^{37}$ Y. Li, Acc. Chem. Res. 45, 723 (2011).

${ }^{38}$ H. J. Son, F. He, B. Carsten, and L. Yu, J. Mater. Chem. 21, 18934 (2011).

${ }^{39}$ H. Zhou, L. Yang, and W. You, Macromolecules 45, 607 (2012).

${ }^{40}$ J. Zaumseil and H. Sirringhaus, Chem. Rev. 107, 1296 (2007).

${ }^{41}$ P. M. Beaujuge and J. M. J. Fréchet, J. Am. Chem. Soc. 133, 20009 (2011).

${ }^{42}$ A. L. Dyer, E. J. Thompson, and J. R. Reynolds, ACS Appl. Mater. Interfaces 3, 1787 (2011).

${ }^{43}$ M. J. Frisch, G. W. Trucks, H. B. Schlegel, G. E. Scuseria, M. A. Robb, J. R. Cheeseman, G. Scalmani, V. Barone, B. Mennucci, G. A. Petersson, H. Nakatsuji, M. Caricato, X. Li, H. P. Hratchian, A. F. Izmaylov, J. Bloino, G. Zheng, J. L. Sonnenberg, M. Hada, M. Ehara, K. Toyota, R. Fukuda, J. Hasegawa, M. Ishida, T. Nakajima, Y. Honda, O. Kitao, H. Nakai, T. Vreven, J. A. Montgomery, Jr., J. E. Peralta, F. Ogliaro, M. Bearpark, J. J. Heyd, E. Brothers, K. N. Kudin, V. N. Staroverov, R. Kobayashi, J. Normand, K. Raghavachari, A. Rendell, J. C. Burant, S. S. Iyengar, J. Tomasi, M. Cossi, N. Rega, J. M. Millam, M. Klene, J. E. Knox, J. B. Cross, V. Bakken, C. Adamo, J. Jaramillo, R. Gomperts, R. E. Stratmann, O. Yazyev, A. J. Austin, R. Cammi, C. Pomelli, J. W. Ochterski, R. L. Martin, K. Morokuma, V. G. Zakrzewski, G. A. Voth, P. Salvador, J. J. Dannenberg, S. Dapprich, A. D. Daniels, O. Farkas, J. B. Foresman, J. V. Ortiz, J. Cioslowski, and D. J. Fox, Gaussian 09, Revision A.02, Gaussian, Inc., Wallingford, CT, 2009.

${ }^{44}$ S. Roquet, A. Cravino, P. Leriche, O. Alévêque, P. Frère, and J. Roncali, J. Am. Chem. Soc. 128, 3459 (2006).

${ }^{45}$ C. M. Cardona, W. Li, A. E. Kaifer, D. Stockdale, and G. C. Bazan, Adv. Mater. 23, 2367 (2011). 